\title{
Detection of immunogenic protein from salivary gland of Aedes albopictus
}

\author{
Rike Oktarianti ${ }^{1}$, Rochmatul Nuryu Khasanah ${ }^{1}$, Syubbanul Wathon ${ }^{1}$, \\ and Kartika Senjarini ${ }^{{ }^{*}}$
}

\begin{abstract}
\section{BACKGROUND}

Dengue virus is transmitted by several species of Aedes mosquitoes, with Aedes albopictus as secondary vector. During blood feeding, these vectors inject saliva into the vertebrate hosts. The saliva contains anticoagulant, anti-inflammatory and immunogenic factors. The objective of this research was to detect immunogenic proteins from Ae.albopictus salivary glands reacting with sera of people living in dengue endemic areas.
\end{abstract}

\section{METHODS}

The identification of immunogenic proteins of Ae. albopictus salivary gland used one-dimensional gel electrophoresis (sodium dodecyl sulfate polyacrylamide gel electrophoresis), and western blot analysis, respectively. To determine the immunogenic nature of the candidate proteins, the antigens from the salivary gland of Ae. albopictus were reacted with sera from healthy persons, dengue hemorrhagic fever (DHF) patients, and neonates, each of the groups comprising 10 samples.

\section{RESULTS}

The protein profiles of Ae. albopictus salivary glands showed 13 bands with molecular weights from $16 \mathrm{kDa}$ up to $97 \mathrm{kDa}$, i.e. $16,17,26,28,31,32$, $45,55,60,67,73,76$, and $97 \mathrm{kDa}$. According to western blot analysis result, the $31 \mathrm{kDa}$ proteins were recognized in all endemic population sera, both in DHF patients and healthy persons. In contrast, protein bands of 47 and 67 $\mathrm{kDa}$ were only recognized by the sera of DHF patients.

\section{CONCLUSION}

Three immunogenic proteins of 31, 47 and $67 \mathrm{kDa}$ were detected from $\mathrm{Ae}$. albopictus salivary glands. These immunogenic proteins may be developed as candidate biomarkers for bite exposure to Ae. albopictus and as vectorbased DHF vaccines.
${ }^{1}$ Department of Biology, Faculty of Mathematics and Natural Sciences, Jember University

Correspondence :

*Kartika Senjarini

Department of Biology,

Faculty of Mathematics and Natural

Sciences, Jember University

JL. Kalimantan No.37, Tegalboto,

Sumbersari, Jember, East Java,

Indonesia

Phone/Fax: +6287857703792

Email: senjarini@unej.ac.id

ORCID ID: 0000-0001-7041-1719

Date of first submission, March 5, 2021

Date of final revised submission, November 8, 2021

Date of acceptance, November 20, 2021

This open access article is distributed under a Creative Commons AttributionNon Commercial-Share Alike 4.0 International License

Cite this article as: Oktarianti R, Khasanah RN, Wathon S, Senjarini K. Detection of immunogenic protein from salivary gland of Aedes albopictus. Univ Med 2021;40:234-42. doi: 10.18051/ UnivMed.2021.v40.234-242.

Keywords : Immunogenic protein, salivary gland, Aedes albopictu 


\section{INTRODUCTION}

Dengue hemorrhagic fever (DHF) often affects people in tropical and subtropical areas. ${ }^{(1)}$ Areas at risk of dengue infection comprise 128 countries, including Indonesia. ${ }^{(2-4)}$ The latest data show that about two-thirds of the world's population has the potential to be infected by dengue, with the number of cases reaching 100390 million each year. ${ }^{(5,6)}$ Dengue hemorrhagic fever (DHF) is caused by infection with the dengue arbovirus which has four serotypes, i.e. dengue virus (DENV)-1, DENV-2, DENV-3, and DENV-4. ${ }^{(7,8)}$ The dengue virus infects the human body through transmission mediated by Aedes mosquitoes (Aedes aegypti and Aedes albopictus). ${ }^{(9)}$ Ae. aegypti is the primary vector because its habitat is around settlements so that it often comes into contact with humans. Ae. albopictus acts as a secondary vector because its habitat is in gardens or forests far from human settlements. At present Ae. albopictus has adapted to rural and suburban environments. ${ }^{(10)}$ Dengue virus transmission to human hosts occurs when the vector is blood feeding. ${ }^{(1)}$ Successful transmission of the dengue virus occurs due to the presence of important proteins in Aedes salivary glands. ${ }^{(12)}$ Aedes saliva has several proteins able to act as antihemostatic, vasodilator, anti-inflammatory, and immunomodulatory substances which play a role in the successful transmission of the dengue virus. ${ }^{(13)}$ Antihemostatic substances play a role in preventing coagulation of host blood when mosquitoes are blood feeding. Vasodilator substances can cause vasodilation of blood capillaries. Immunomodulators are substances that can suppress the host immune response so that it can increase the transmission of pathogens into the host by modulating the host immune response so as to facilitate their transmission into the host. ${ }^{(12,14)}$

Immunomodulatory proteins in arthropod saliva cause a shift in the immune response towards $\mathrm{T}$ helper type 2 (Th2), characterized by increased production of Th2 cytokines such as interleukin-4 (IL-4) and IL-10 and decreased production of Th1 cytokines such as interferon gamma (IFN- $\gamma$ ) and IL-12. ${ }^{(13)}$ Repeated exposure can increase production of specific antibodies in the host against salivary proteins. This is because when the host is repeatedly exposed, there will be an increase in the proliferation of B cells into plasma cells and memory cells which will cause the production of immunoglobulin $\mathrm{G}$ ( $\mathrm{IgG})$. The increase in IgG production will trigger the host's immunity against pathogens. IgG production can also be used as a marker for the presence of immunogenic proteins in mosquito saliva. ${ }^{(15,16)}$

Previous research identified two immunogenic proteins from Ae. aegypti salivary glands of 31 and $56 \mathrm{kDa}$, respectively. ${ }^{(17)}$ Both of these proteins were recognized in sera samples of healthy persons and DHF patients living in DHF endemic areas, but not in sera samples of healthy persons in non-endemic areas and in infants (neonates). This shows that persons living in endemic areas develop specific antibodies. Because Ae. albopictus is also known to be a potential vector of DHF, it is suspected that the salivary glands of $A e$. albopictus contain immunogenic proteins similar to those in Ae. aegypti. Therefore, further research is needed to detect the immunogenic protein fraction in the salivary glands of $A e$. albopictus. The immunogenic protein fraction can be used as a candidate target for the development of vector-based DHF vaccines and as a biomarker of exposure to Ae. albopictus. Therefore, the aim of this study was to detect the immunogenic proteins from the salivary glands of Ae. albopictus.

\section{METHODS}

\section{Research design}

A laboratory study was conducted from January to November 2020 at the Biotechnology Laboratory, Department of Biology, Faculty of Mathematics and Natural Sciences (FMIPA), Jember University. 


\section{Research subjects}

Thirty sera samples were taken from healthy persons, DHF patients, and infants (neonates) living in Jember, consisting of 10 samples each. The inclusion criteria of healthy sample sources were persons aged 15-50 years who never had DHF, whereas DHF patients as sample source were persons aged 15-50 years diagnosed as having DHF by a doctor. The exclusion criteria of sample sources were persons under 15 years old or more than 50 years old and non-residents of Jember.

The study commenced with the rearing of Ae. albopictus mosquitoes and was then continued by the identification of Ae. albopictus based on morphological characters, isolation of the salivary glands, extraction of salivary gland proteins, protein profile analysis using sodium dodecyl sulphate polyacrylamide gel electrophoresis (SDS-PAGE), and finally western blot analysis to identify immunogenic proteins.

\section{Rearing of Ae. albopictus}

Rearing was conducted at the Animal Care Unit, University of Jember, at room temperature $\left(27^{\circ} \mathrm{C}\right)$. Rearing was begun with the landing collection of Ae. albopictus mosquitoes using aspirators in gardens around the University of Jember. Male mosquitoes were fed 10\% sucrose solution, while female mosquitoes were fed by blood feeding.

\section{Species identification based on morphological characters}

Identification of species based on morphological characters was carried out prior to isolation of the salivary glands. Ae. albopictus and Ae. aegypti are easily distinguished by the mesonotum, mesepimeron, and femur. The mesonotum in Ae. aegypti has rows of white hairs forming a white line pattern, namely two curved white lines like a lyre and two parallel lines, while in Ae. albopictus it has only one white line. The mesepimeron of the two mosquitoes is very different: Ae. aegypti has a collection of white scales forming two separate white patches, whereas Ae. albopictus has a single white patch. Ae. aegypti has rows of white hairs that form a long white stripe on the anterior femoral surface of the middle leg, while Ae. albopictus does not have such a femoral stripe. ${ }^{(10)}$

\section{Isolation and extraction of Ae. albopictus salivary gland proteins}

Isolation of the salivary glands was by microdissection using a dissection needle, in which the investigator's left hand gently presses on the thoracic part and the right hand slowly pulls on the head, so that the 6 clear salivary glands appear. ${ }^{(18)}$ The salivary glands that have been obtained are then separated from the fat body or other tissues until they are clean and then put into a microtube containing $10 \mu \mathrm{l}$ of 1 $\mathrm{mM}$ phenylmethylsulfonyl fluoride (PMSF) in phosphate buffered solution (PBS) in the ratio of $1: 1$ for the 10 pairs of salivary gland samples and stored at $-20^{\circ} \mathrm{C}$ until used. Salivary gland protein extraction was carried out by adding 10 $\mu 1$ of sample buffer into a microtube containing 10 pairs of salivary gland samples $+10 \mu 1$ of 1 $\mathrm{mM}$ PMSF in PBS. The extraction process was followed by boiling using a thermoshaker at a temperature of $95^{\circ} \mathrm{C}$ for 4 minutes. After boiling, the salivary gland protein extract was centrifuged to obtain the supernatant.

\section{Blood sera preparation}

Thirty serum samples were taken from healthy persons, DHF patients, and infants (neonates) living in Jember, East Java, a region within the endemic range for dengue, each group comprising 10 samples. These samples were collected in 4 months from July-October 2020. The serum samples of DHF patients were taken from the Dokterku Clinic and Citra Husada Hospital, Jember. Neonatal serum samples were taken from the Umi Soemarno Clinic, Jember. Blood samples were taken from the brachial veins in the upper arm, except for neonatal sera which were taken from the portion of the umbilical cord that remained with the baby after birth. Each blood 
sample had a volume of $3 \mathrm{ml}$ and was stored in a vacutainer without anti-coagulant. The blood samples were allowed to stand for 30 minutes, then the top clear layer was taken and centrifuged at $3200 \mathrm{rpm}$ for $15 \mathrm{~min}$ at $4^{\circ} \mathrm{C}$. The resulting supernatant after centrifugation constituted the serum. The serum samples were stored at $-20^{\circ} \mathrm{C}$ until used.

\section{Protein profile analysis of Ae. albopictus salivary glands}

The salivary gland protein profile of $A e$. albopictus was analyzed using SDS-PAGE. Electrophoresis of the protein samples was done using $12 \%$ separating gel and $4 \%$ stacking gel. Each well in the gel contained $20 \mu \mathrm{l}$ of protein sample (10 pairs of salivary gland samples in 10 $\mu 1$ of PMSF in PBS $+10 \mu 1$ of sample buffer). Electrophoresis was carried out at a constant voltage of $150 \mathrm{~V}$ for 100 minutes in a running buffer. Then the gel underwent a coloring process using coomassie brilliant blue dye solution (staining) for 60 minutes. The washing process (destaining) was performed 3 times using trisbuffered saline (TBS) every 30 minutes to remove the dye solution that was not bound to protein.

\section{Identification of the immunogenic protein fraction from Ae. albopictus salivary glands}

Identification of immunogenic protein fractions was carried out by western blot analysis, with several modified steps using the semi-dry method. ${ }^{(19)}$ Proteins in the polyacrylamide gel from SDS-PAGE analysis were transferred to the polyvinylidene fluoride (PVDF) membrane for 1 hour with a constant current of $100 \mathrm{~mA}$. The PVDF membranes were cut according to the size of the polyacrylamide gel then immersed in methanol for 1 minute. The polyacrylamide gel, PVDF membrane, 2 sheets of Whatman filter paper, and fiber pad were immersed in the transfer buffer prior to western blot analysis. The PVDF membrane, SDS-PAGE acrylamide gel, filter paper, and blotting paper (fiber pad) were arranged sequentially.
The immunoblotting process was followed by a reaction between the salivary gland proteins of Ae. albopictus on the membranes and primary antibodies derived from sera of healthy persons in DHF endemic areas, as well as DHF patients and neonates, that were dissolved in 5\% skim milk in TBS $(1: 250)$ then incubated overnight at $4^{\circ} \mathrm{C}$. The membrane was washed with 3 TBS times for 5 minutes each. The secondary antibody used was goat - anti human IgG alkaline phosphatase conjugate (ROCKLAND, USA) which was dissolved in 5\% skim milk in TBS (1: 2500). The membranes that had been treated with secondary antibodies were then incubated for 2 hours. Visualization was done by adding the nitro blue tetrazolium-(5-bromo-4-chloro-3-indolylphosphatase) (NBT-BCIP) alkaline phosphatase substrate (ROCKLAND, USA) to the brackets and incubating in a dark room for 1 minute until immunogenic protein bands appeared. The membranes were washed with distilled water to stop the reaction. Positive western blot results were shown by bands on the PVDF membrane, indicating the presence of binding between the antigens from the Ae. albopictus salivary gland proteins and primary antibodies.

\section{Ethical clearance}

All participants gave written, informed consent to take part in the study. The collecting protocol was approved by the Ethical Committee of Medical Research, Faculty of Dentistry, University of Jember under No. 1034/UN25.8/ KEPK/DL/2020

\section{RESULTS}

The structure of the Ae. albopictus salivary glands consists of two parts connected by the salivary duct. Each part has three lobes, namely two lateral lobes (L) and one medial lobe (M). Each of the lateral lobes consists of two parts, namely the proximal lobe (PL) and distal lobe (DL). The structure of the salivary glands can be seen in Figure 1. 


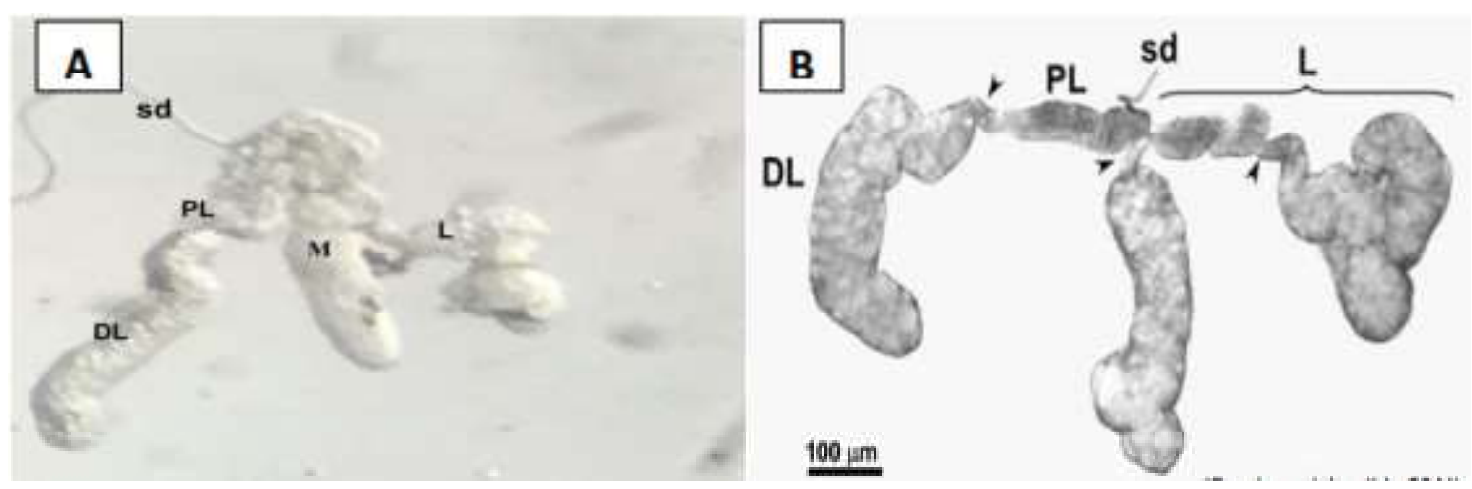

Figure 1. Structure of salivary glands of Ae.albopictus (A) and Ae.aegypti (B). Salivary duct (sd), lateral lobe (L), proximal lobe (PL), distal lobe (DL), medial lobe (M). 50x magnification on the Nikon SMZ735 microscope. Camera: Xiaomi Note 6 Pro.

The protein profile analysis of salivary gland extract of Ae. albopictus was conducted by using SDS PAGE. The results showed that the salivary gland proteins from Ae. albopictus have 13 protein bands with molecular weights of 16,17 , $26,28,31,32,45,55,60,67,73,76$, and $97 \mathrm{kDa}$, respectively, as can be seen in Figure 2.

Analysis of the immunogenicity of the salivary gland proteins of Ae. albopictus was performed by western blot analysis of the crossreaction between the antigens (salivary gland proteins) and the sera of healthy persons living in endemic areas, DHF patients, and neonates (as negative controls). The $31 \mathrm{kDa}$ immunogenic protein can be recognized by all endemic population sera, both the sera of DHF patients and healthy persons. Meanwhile, the 47 and 67 $\mathrm{kDa}$ protein bands were only recognized by the sera of DHF patients (Figure 3).

\section{DISCUSSION}

The results of SDS-PAGE analysis of the salivary gland protein extracts from $A e$. albopictus showed 13 protein bands, which are thought to have certain roles such as in anti-host homeostasis and are involved in the metabolism of the mosquito's body. The role of the $97 \mathrm{kDa}$ and $79 \mathrm{kDa}$ proteins is unknown. The $60-70 \mathrm{kDa}$ proteins are thought to contain apyrase which functions to inhibit platelet aggregation. ${ }^{(16,20-22)}$ The proteins with molecular weights ranging from 40 to $55 \mathrm{kDa}$ are serpins which function as

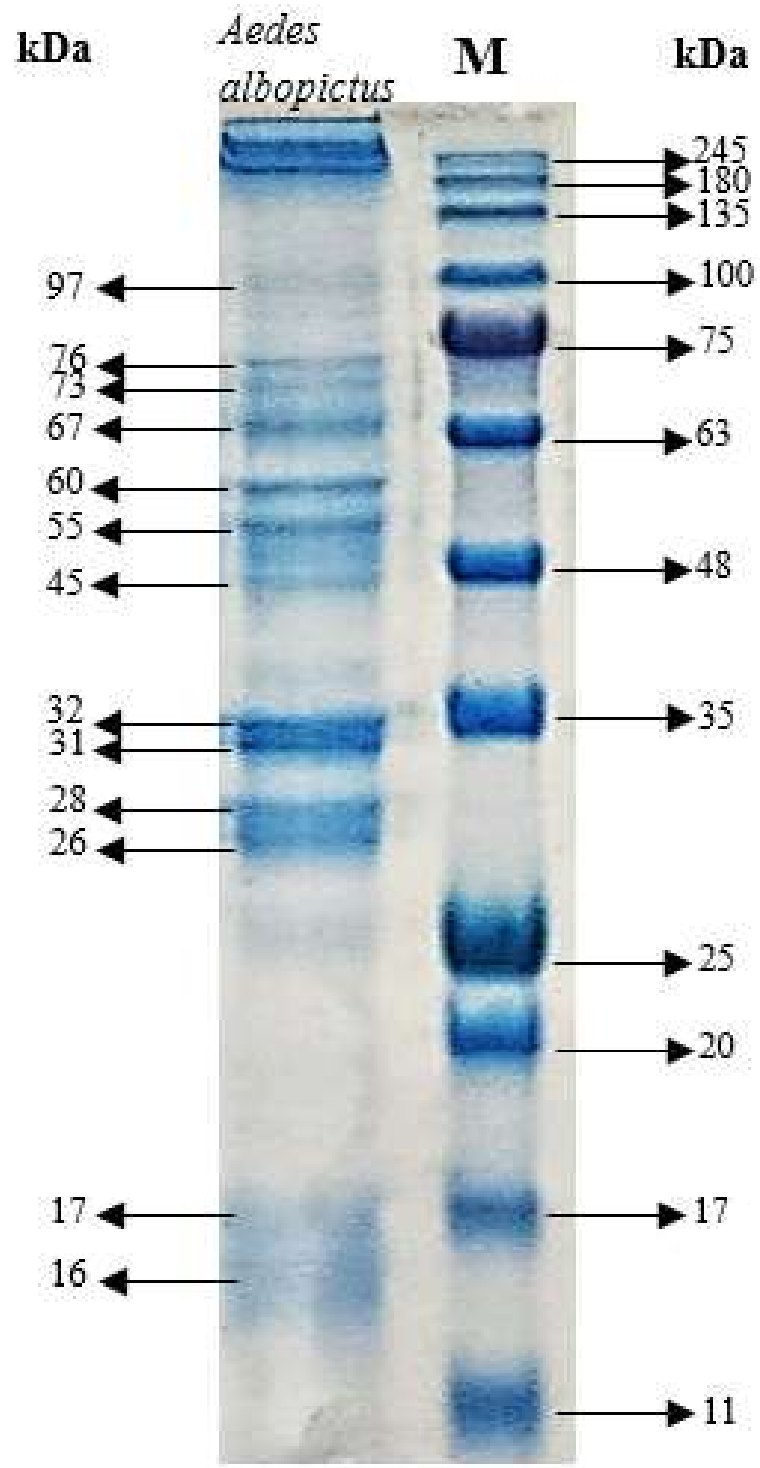

Marker: Prestained Blue Eye PS-104 (M)

Figure 2. Salivary gland protein profile of $A e$. albopictus (Samsung A50 camera) 


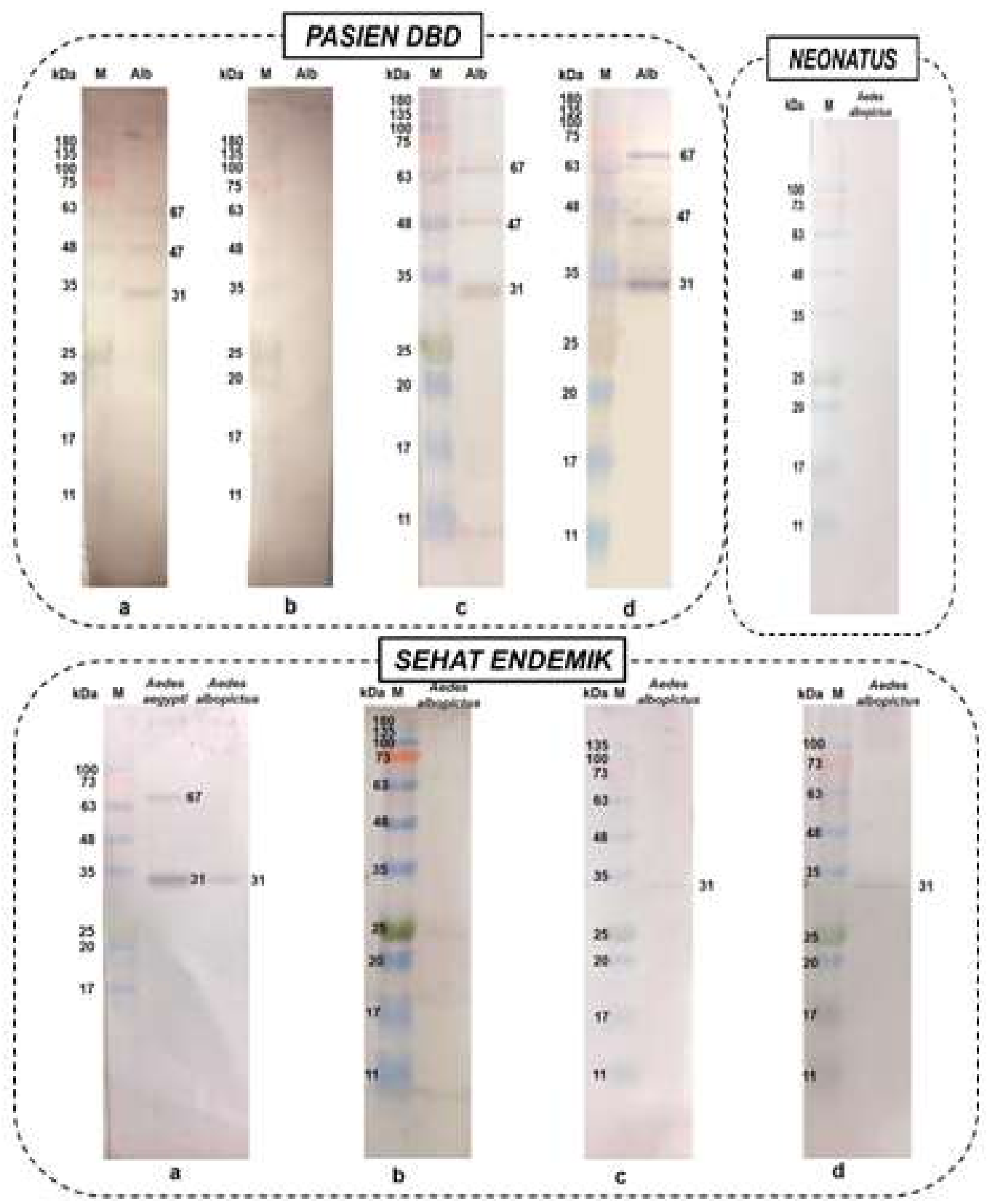

Figure 3. Results of the immunogenicity analysis of the Ae. albopictus salivary gland proteins in individual sera (a, b, c and d) of DHF patients, healthy persons, and neonates (Samsung A50 camera)

Indonesian abbreviations: Pasien DBD [Demam Berdarah Dengue] = Dengue Hemorrhagic Fever patients Sehat Endemik = healthy endemic [sera]

protease inhibitor and anticoagulant. Approximately 500 serpins are currently known, consisting of between 350 and 400 amino acids. (23) The $31 \mathrm{kDa}$ protein is a $\mathrm{D} 7$ protein that acts as vasodilator, immunomodulatory and anticoagulant substance. ${ }^{(17)}$ The $27-29 \mathrm{kDa}$ bands contain immunogenic proteins and are present in all Aedes mosquitoes. ${ }^{(21,22)}$ The $17 \mathrm{kDa}$ band has
D7 family proteins and lectins, which function in opsonization and as antimicrobials. These proteins control microbial growth on sucrose in the mosquito's midgut. ${ }^{(24)}$

Apyrase (ATP-diphosphohydrolase) contained in the $60-70 \mathrm{kDa}$ bands is an enzyme released by Ae. albopictus and other hematophagous arthropods during blood feeding 
that functions as platelet aggregation inhibitor. ${ }^{(25)}$ The $67 \mathrm{kDa}$ molecular weight protein in our study is thought to contain apyrase and $\alpha$-glucosidase. The latter acts as an allergen that will induce $\operatorname{IgE}$ in humans. This enzyme is also released when mosquitoes suck blood and sugar so that the sugar and blood are not mixed in the mosquito's mid gut. ${ }^{(26,27)}$ The apyrase of Ae. albopictus is in the molecular weight range of $61 \mathrm{kDa}$ to 68 kDa. ${ }^{(16,20,28,29)}$

Western blot analysis of the Ae. albopictus salivary gland proteins showed 3 immunogenic proteins of 31, 47 and $67 \mathrm{kDa}$, respectively. The $47 \mathrm{kDa}$ band contains the main protein thought to be a serpin which functions as an anticoagulant. (23) In addition, serpins in the body of insects play a role as proteinase inhibitors. Serine is a proteinase that breaks down the polypeptide bonds produced by pathogens such as viruses. The action of serine is inhibited by a serineprotease inhibitor, namely serpin. ${ }^{(30)}$ Serpins that enter the host are thought to inhibit the action of serine so that the transmission of the dengue virus runs smoothly. DHF patients also activate B cells to produce more antibodies, so the serum of DHF patients are able to recognize more immunogenic proteins. Samples taken from each individual presumably reflect the various responses of the individuals to the different antigens carried by the mosquitoes.

From the western blot analysis results in Figure 3, it is apparent that the immunogenicity analysis of sera of the endemic population shows different bands for each individual. This is presumably because of the differing responses of each individual to exposure to antigens carried by mosquitoes. The intensity of exposure to Aedes salivary antigens in endemic areas will influence the human immune system to form specific antibodies (IgG) against these antigens. ${ }^{(15,31)}$

Exposure to antigens for the first time (primary) will activate the T cells and B cells. The $B$ cells will differentiate and proliferate to produce IgG in small amounts. The T cells will be activated by the antigens to become memory cells upon secondary or multiple exposure to the antigens. Re-exposure (secondary) to the same antigen will produce more IgG. ${ }^{(32)}$ Apyrase, serpins, and the D7 family are thought to be the most immunogenic proteins in the salivary glands, so that even low titers can trigger the formation of antibodies in the host body. These three proteins are thought to be immunogenic because they can modulate the immune response of the host.

The band of $31 \mathrm{kDa}$ is the $\mathrm{D} 7$ immunogenic family which facilitates the process of blood feeding. The D7 family functions as a vasodilator, immunomodulator, and anticoagulant. ${ }^{(33)}$ The protein of $47 \mathrm{kDa}$ is serpin, that acts as anticoagulant and anti-inflammatory, ${ }^{(23,25,26)}$ where as the band of $67 \mathrm{kDa}$ is apyrase, that acts as allergen and anticoagulant. The abovementioned three proteins are thought to trigger modulation of the host's immune response because they comprise proteins that act as allergens and immunomodulators. Allergens will react with $\mathrm{IgE}$ and cause inflammation in the host. ${ }^{(26,27)}$ The immunomodulators function to modulate the host's immune response so that they can increase the transmission of pathogens into the host. ${ }^{(24)}$

Neonate serum samples were not recognized as containing immunogenic proteins, presumably because there was no binding between antigens of salivary gland proteins and serum antibodies. This is in accordance with previous research which stated that no immunogenic protein was recognized by neonate sera samples. ${ }^{(33)}$ Neonate samples were obtained from the umbilical cord of the baby at birth, thus the neonate samples had never been directly exposed to Ae. albopictus salivary gland proteins so that no immunogenic proteins were identified. The three immunogenic proteins of 31, 47 and 67 $\mathrm{kDa}$ from the salivary glands can be used as biomarker protein candidate for bite exposure to Ae. albopictus and can be developed into a vector-based DHF vaccine. Therefore, further studies are needed to determine the identities of these proteins and their biological functions in dengue virus transmission and blood feeding using transcriptomic or proteomic analysis. The limitation of this study was the sera samples were 
only taken from one DHF endemic region i.e. Jember, East Java - Indonesia. Therefore, further investigation in the several endemic regions is needed to find out the relevancy of the data".

\section{CONCLUSIONS}

This study demonstrated 3 immunogenic proteins that were identified from the salivary glands of Ae. albopictus of 31, 47 and $67 \mathrm{kDa}$, respectively. The $31 \mathrm{kDa}$ protein fraction could be recognized by all endemic population sera, both the sera of endemic DHF and healthy patients. In contrast, the 67 and $47 \mathrm{kDa}$ fractions were only recognized by the sera of DHF patients. These immunogenic proteins can be used as biomarker candidates for bite exposure to $A e$. albopictus and can be developed into a vectorbased DHF vaccine.

\section{CONFLICT OF INTEREST}

The authors declare that there are no conflicts of interest.

\section{ACKNOWLEDGEMENT}

This study was financially supported by "Hibah Penelitian Pendukung IDB" - Internal Financial (PNBP) of Jember University.

\section{CONTRIBUTORS}

RO conceived and planned the experiments and wrote the manuscript. RNK carried out the experiment and contributed to the interpretation of the results. SW contributed to sample preparation and interpretation of the results. KS conceived the original idea and supervised the project. All authors have read and approved the final manuscript.

\section{REFERENCES}

1. Hadinegoro SRS. The revised WHO dengue case classification: Does the system need to be modified? Paediatr Int Child Health 2012;32:33-8. doi: 10.1179/2046904712Z.00000000052.

2. Sandra T, Sofro MA, Suhartono S, Martini M, Hadisaputro S. Faktor yang berpengaruh terhadap kejadian demam berdarah dengue pada anak usia 6-12 tahun. J Ilm Permas J Ilm STIKES Kendal 2019;9:28-35. http://dx.doi.org/10.32583/ pskm.9.1.2019.28-35.

3. Zhang H, Lui R. Releasing Wolbachia-infected Aedes aegypti to prevent the spread of dengue virus: a mathematical study. Infect Dis Model 2020;5:142-60. https://doi.org/10.1016/j.idm.2019. 12.004 .

4. Koh C, Allen SL, Herbert RI, Mcgraw EA. The transcriptional response of Aedes aegypti with variable extrinsic incubation periods for dengue virus. Genome Biol Evol 2018;10:3141-51. https:/ /doi.org/10.1093/gbe/evy230.

5. Ahammad F, Tengku Abd Rashid TR, Mohamed M, Tanbin S, Fuad FAA. Contemporary strategies and current trends in designing antiviral drugs against dengue fever via targeting host-based approaches. Microorganisms 2019;7:296. https:/ /doi.org/10.3390/microorganisms7090296.

6. Sun B, Zhang X, Zhang H, et al. Genomic epidemiological characteristics of dengue fever in Guangdong province, China from 2013 to 2017. PLoS Negl Trop Dis 2020;14: e0008049. https:// doi.org/10.1371/journal.pntd.0008049.

7. Liu Y, Zhang F, Liu J, et al. Transmission-blocking antibodies against mosquito C-type lectins for dengue prevention. PLoS Pathog 2014;10: e1003931. http://dx.doi.org/10.1371/journal.ppat. 1003931.

8. Londono-Renteria B, Troupin A, Conway MJ, et al. Dengue virus infection of Aedes aegypti requires a putative cysteine rich venom protein. PLoS Pathog 2015;11: e1005202. http://dx.doi.org/ 10.1371/journal.ppat.1005202.

9. Wan SW, Lin CF, Wang S, et al. Current progress in dengue vaccines. J Biomed Sci 2013;20:37. https://doi.org/10.1186/1423-0127-20-37.

10. Rahayu DF, Ustiawan A. Identifikasi Aedes aegypti dan Aedes albopictus. Balaba J Litbang Pengendali Penyakit Bersumber Binatang Banjarnegara 2013;9:7-10.

11. Sun P, Nie K, Zhu Y, et al. A mosquito salivary protein promotes flavivirus transmission by activation of autophagy. Nat Commun 2020;11: 260. http://dx.doi.org/10.1038/s41467-019-14115$\mathrm{z}$

12. Guerrero D, Cantaert T, Missé D. Aedes mosquito salivary components and their effect on the immune response to Arboviruses. Front Cell Infect 
Microbiol 2020;10:1-11.http://dx.doi.org/10.3389/ fcimb.2020.00407.

13. Fontaine A, Diouf I, Bakkali N, et al. Implication of haematophagous arthropod salivary proteins in host-vector interactions. Parasites Vectors 2011;44: 187.http://dx.doi.org/10.1186/1471-216413-614.

14. Martin-Martin I, Smith LB, Chagas AC, et al. Aedes albopictus D7 salivary protein prevents host hemostasis and inflammation. Biomolecules 2020;10:1-17. doi: 10.3390/biom10101372.

15. Manning JE, Morens DM, Kamhawi S, Valenzuela JG, Memoli M. Mosquito saliva: the hope for a universal arbovirus vaccine? J Infect Dis 2018; 218:7-15. doi: 10.1093/infdis/jiy179.

16. Doucoure S, Cornelie S, Patramool S, et al. First screening of Aedes albopictus immunogenic salivary proteins. Insect Mol Biol 2013;22:41123. http://dx.doi.org/10.1111/imb.12032 .

17. Oktarianti R, Senjarini K, Hayano T, Fatchiyah F, Aulanni'am. Proteomic analysis of immunogenic proteins from salivary glands of Aedes aegypti. J Infect Public Health 2015;8:575-82. http:// dx.doi.org/10.1016/j.jiph.2015.04.022.

18. Schmid MA, Kauffman E, Payne A, Harris E, Kramer LD. Preparation of mosquito salivary gland extract and intradermal inoculation of mice. Bio Protoc 2017;7:e2407. doi: 10.21769/ BioProtoc.2407.

19. Liu Y, Zhang F, Liu J, et al. Western Blot comparison of wet transfer and semi-dry transfer methods. Parasites Vectors 2011;10:54-64. http:/ /dx.doi.org/10.1016/j.jiph.2015.04.022.

20. Oktarianti R, Wathon S, Indrasari IF, Fitriani NR, Senjarini K. Platelet aggregation in vitro analysis of $67 \mathrm{kDa}$ immunogenic fraction from Aedes albopictus salivary gland. Bioedukasi 2020;18:47-52. http://dx.doi.org/10.19184/ bioedu.v18i2.18891.

21. Wasinpiyamongkol L, Patramool S, Thongrungkiat $\mathrm{S}$, et al. Protein expression in the salivary glands of dengue-infected Aedes aegypti mosquitoes and blood-feeding success. Southeast Asian J Trop Med Public Health 2012; 43:1346-57.

22. De Carvalho IL, Rocha DK, AlmeidaAPG. Immune reactivity to dengue and Aedes albopictus mosquitoes in the population from Macao, China, before dengue occurrence. In Vivo (Brooklyn) 2011;25:625-31.
23. Calvo E, Mizurini DM, Sá-Nunes A, et al. Alboserpin, a factor $\mathrm{Xa}$ inhibitor from the mosquito vector of yellow fever, binds heparin and membrane phospholipids and exhibits antithrombotic activity. J Biol Chem 2011;286: 27998-8010. doi: 10.1074/jbc.M111.247924.

24. Luplertlop N. Aedes mosquito salivary immune peptides: boost or block dengue viral infections. J Coast Life Med 2014;2:163-8. doi:10.12980/ JCLM.2.2014C1219.

25. Masoud HMM, Helmy MS, Darwish DA, AbdelMonsef MM, Ibrahim M.A. Apyrase with antiplatelet aggregation activity from the nymph of the camel tick Hyalomma dromedarii. Exp Appl Acarol 2020;80:349-61. doi: 10.1007/s10493-02000471-9.

26. Juhn J, Naeem-Ullah U, MacIel Guedes BA, et al. Spatial mapping of gene expression in the salivary glands of the dengue vector mosquito, Aedes aegypti. Parasites Vectors 2011;4:1-13. http:// dx.doi.org/10.1186/1756-3305-4-1.

27. Peng Z, Caihe L, Beckett AN, Guan Q, James AA, Simons FER. rAed a 4: a new 67-kDa Aedes aegypti mosquito salivary allergen for the diagnosis of mosquito allergy. Int Arch Allergy Immunol 2016;170:206-10. DOI: https://doi.org/ 10.1038/s41467-019-14115-Z

28. Wichit S, Ferraris P, Choumet V, Missé D. The effects of mosquito saliva on dengue virus infectivity in humans. Curr Opin Virol 2016;21:139 45. doi: 10.1016/j.coviro.2016.10.001.

29. Dong F, Fu Y, Li X, Jiang J, Sun J, Cheng X. Cloning, expression, and characterization of salivary apyrase from Aedes albopictus. Parasitol Res 2012;110:931-7. doi: 10.1007/s00436-0112579-x.

30. Meekins DA, Kanost MR, Michel K. Serpins in arthropod biology. Semin Cell Dev Biol 2017; 62:105-19. doi: 10.1016/j.semcdb.2016.09.001.

31. Doucoure S, Mouchet F, Cornelie S, et al. Evaluation of the human IgG antibody response to Aedes albopictus saliva as a new specific biomarker of exposure to vector bites. PLoS Negl Trop Dis 2012;6:e1487. doi:10.1371/journal.pntd. 0001487.

32. Bratawijaya K, Rengganis I. Basic immunology. 11th ed. Jakarta: Publishing Agency of the Faculty of Medicine, University of Indonesia; 2014.

33. Oktarianti R, Senjarini K, Fatchiyah F, Aulanni'am. Immunogenic protein from salivary gland of Aedes aegypti against to human sera. Adv Nat Appl Sci 2014;8:101-7. 